\title{
Melt pockets in sheared garnet lherzolite xenoliths from the Udachnaya-East kimberlite pipe (Yakutia, Russia)
}

\author{
Igor S. Sharygin, Alexander V. Golovin and Nikolai P. Pokhilenko \\ Institute of Geology and Mineralogy, Novosibirsk, Russia
}

\section{Introduction}

Interstitial melt pockets and veins in mantle xenoliths as well as melt inclusions, trapped by minerals of xenoliths, are samples of actual mantle melts or fluids available for us to study. Investigation of ones provides significant information on processes within the subcontinental lithospheric mantle. The interstitial melt pockets and veins were formed after rock-forming mineral assemblage of xenoliths. They can be produced by decompression melting of mantle minerals of xenoliths after trapping by host magmas (e.g., Tracy, 1980), partial melting of primary minerals in mantle (e.g., Spetsius, Taylor, 2002), metasomatic events in mantle before (e.g., Ionov et al., 1993) and after trapping by host magma (e.g., Misra et al., 2004).

\section{Sample description}

We have studied 20 xenoliths of unaltered sheared garnet lherzolite from uniquely fresh kimberlites from the Udachnaya-East pipe (Yakutia, Russia). The sheared xenoliths show porphyroclastic to fluidalmosaic-porphyroclastic textures (based on the classification of Harte, 1977). The rock-forming mineral assemblage of these xenoliths is composed of olivine, orthopyroxene, clinopyroxene and garnet. The $\mathrm{P}-\mathrm{T}$ conditions of formation for these paragenesis, based on geothermobarometer of (Brey, Köhler, 1990), can be estimated as $\mathrm{P}=61-74 \mathrm{~kb}$ and $\mathrm{T}=1230-1370$ ${ }^{\circ} \mathrm{C}$. Melt pockets were recognized in all of the studied xenoliths. Melt inclusions in primary minerals also occur in the studied samples (Golovin et al., 2008).

Melt pockets are localized among rock-forming minerals. Their size is variable (up to $200 \mu \mathrm{m}$ ). Individual interstitial melt pockets often connected to each other by thin $(5-25 \mu \mathrm{m})$ melt veins. The melt pockets (Fig. 1) and veins consist of olivine, monticellite, clinopyroxene, phlogopite, tetraferriphlogopite, sodalite, zoned spinel (chromite, Ti-magnetite, magnetite), perovskite, apatite, calcite and sulfides (monosulfide solid solution, pentlandite, pyrrhotite and djerfisherite).

\section{Chemistry of minerals in melt pockets}

The chemical composition of minerals in melt pockets was determined on a CAMEBAX electron microprobe at the Institute of Geology and Mineralogy (Novosibirsk, Russia) using standard technique.
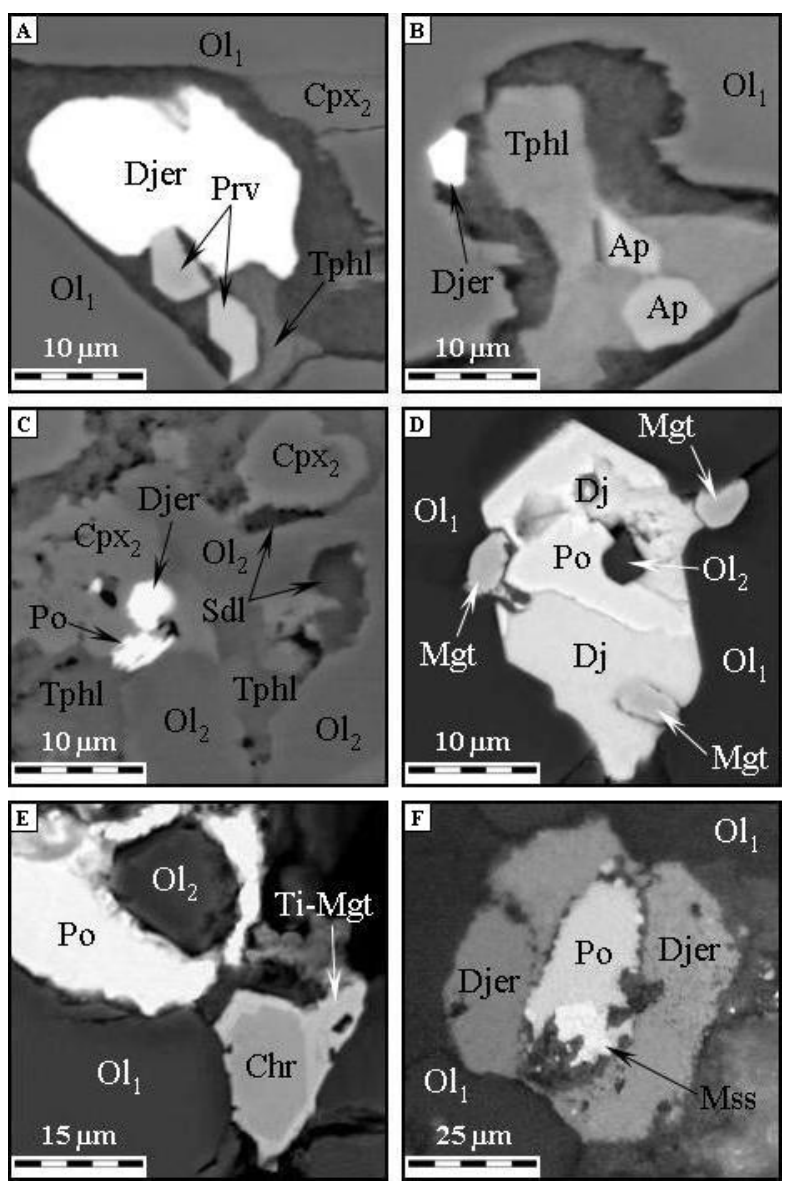

Fig 1. Photomicrograph of the melt pockets in sheared lherzolite xenoliths from the Udachnaya-East pipe. A-E - BSE images; F - reflected light. Symbols: $\mathrm{Ol}_{1}$ - primary olivine; $\mathrm{Ol}_{2}-$ interstitial olivine; $\mathrm{Cpx}_{2}-$ interstitial clinopyroxene; Tphl - tetraferriphlogopite; Sdl - sodalite; Chr - chromite; Mgt - magnetite; Ti-Mgt - Ti-magnetite; Prv - perovskite; Ap - apatite; Po - pyrrhotite; Mss - monosulfide solid solution; Djer - djerfisherite.

Olivine. The composition of olivine of the melt pockets notably differs from that of primary olivine in xenoliths and varies within the following ranges (in wt.\%): 41.141.6 $\mathrm{SiO}_{2}$; 5.5-6.5 FeO; 0.3-0.4 MnO; 51.3-52.1 MgO; 0.1-0.5 CaO; up to $0.1 \mathrm{NiO}$. On the diagram (Fig. 2), olivines of the melt pockets form individual field. Only two points are localized near field of primary olivines. These points are central part of large grains of interstitial olivine. The contents of $\mathrm{CaO}$ and $\mathrm{MnO}$ in these olivines are higher than in the primary olivines. 


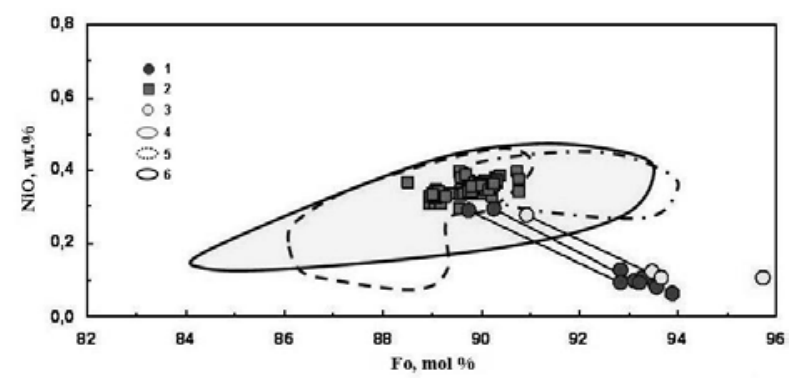

Fig. 2. Compositional variations of olivine in melt pockets of sheared lherzolite xenoliths from Udachnaya-East pipe. 1 - in melt pockets; 2 - primary olivine of xenoliths; 3 - in secondary melt inclusions in olivine from host kimberlites of the Udachnaya-East pipe (Golovin et al., 2007); 4 - anhedral olivine phenocrysts from kimberlites of the UdachnayaEastern pipe (Golovin et al., 2007); 5 - from kimberlite groundmass of the Udachnaya-Eastern pipe (Golovin et al., 2007); 6 - from inclusions in diamonds of Yakutia (Sobolev et al., 2004). The lines connect core and rim of individual grains.

Monticellite contains (in wt.\%): 36.5-37.8 $\mathrm{SiO}_{2} ; 2.1-5.7$ $\mathrm{FeO}$; 0.2-0.4 MnO; 21.8-27.0 MgO; 32.1-27.0 CaO.

Clinopyroxene of the melt pockets notably differs in composition from primary clinopyroxene. It is diopside $\left(\mathrm{En}_{47-54} \mathrm{Fs}_{2-7} \mathrm{Wo}_{46-51}\right)$. It shows variable composition particularly in $\mathrm{TiO}_{2}\left(0.2-1.0\right.$ wt.\%), $\mathrm{Cr}_{2} \mathrm{O}_{3}$ (up to 1.4 wt.\%), $\mathrm{Al}_{2} \mathrm{O}_{3}$ (up to 1.9 wt.\%), $\mathrm{Na}_{2} \mathrm{O}$ (0.2-1.6 wt.\%) and $\mathrm{K}_{2} \mathrm{O}$ (up to 0.9 wt.\%).
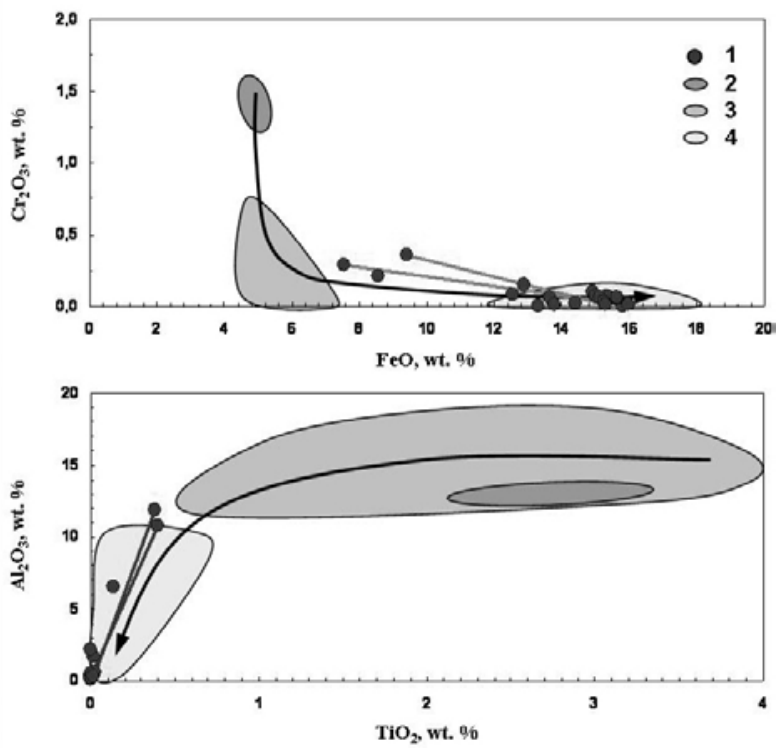

Fig. 3. Compositional variations (in wt.\%) of micas in melt pockets (1) in sheared lherzolite xenoliths from Udachnaya-East pipe. Compositional fields of micas from the kimberlites of the Udachnaya-East pipe (Golovin et al., 2007): 2 - crystalline phlogopite inclusions in olivine from kimberlite groundmass; 3 phlogopite from groundmass; 4 - tetraferriphlogopite of secondary melt inclusions in olivine. The lines connect core and rim of individual grains.
Micas. Phlogopite shows the following compositional variations (in wt.\%): 40.0-41.4 $\mathrm{SiO}_{2} ; 0.1-0.4 \mathrm{TiO}_{2}$; 0.2$0.4 \mathrm{Cr}_{2} \mathrm{O}_{3} ; 10.8-11.9 \mathrm{Al}_{2} \mathrm{O}_{3} ; 7.6-9.4 \mathrm{FeO}$; up to 0.1 $\mathrm{MnO}$; 25.8-26.1 $\mathrm{MgO}$; up to $0.2 \mathrm{CaO}$; 0.2-0.7 $\mathrm{BaO}$; 0.3-0.5 $\mathrm{Na}_{2} \mathrm{O}$; 9.5-9.9 $\mathrm{K}_{2} \mathrm{O}$; 0.9-1.2 F; up to $1.1 \mathrm{Cl}$. The composition of tetraferriphlogopite is also variable (in wt.\%): 37.9-40.1 $\mathrm{SiO}_{2}$; up to $0.2 \mathrm{Cr}_{2} \mathrm{O}_{3}$; up to 0.1-2.2 $\mathrm{Al}_{2} \mathrm{O}_{3}$; 12,5-16,0 FeO; up to 0.1 MnO; 23.6-29.0 MgO; up to $0.1 \mathrm{CaO}$; up to $0.2 \mathrm{BaO} ; 0.1-0.6 \mathrm{Na}_{2} \mathrm{O}$; 9.9-10.9 $\mathrm{K}_{2} \mathrm{O}$; 0.2-1.0 F; up to $0.1 \mathrm{Cl}$. On the diagrams (Fig. 3), general compositional trend of micas from the host kimberlites is similar to that of micas of melt pockets in xenoliths.

Calcite varies within the following ranges (in wt.\%): 51.3-55.1 CaO; 0.2-0.6 FeO; up to 0.7 $\mathrm{MnO}$; 0.1-3.4 $\mathrm{MgO}$; up to 0,1 $\mathrm{BaO}$; 0.7-1.7 $\mathrm{SrO}$; 0.1-1.6 $\mathrm{Na}_{2} \mathrm{O}$; up to $0.1 \mathrm{~K}_{2} \mathrm{O}$; up to $0.1 \mathrm{SO}_{3}$; 0.1-0.9 $\mathrm{P}_{2} \mathrm{O}_{5}$.

Djerfisherite of the melt pockets is characterized by wide compositional range (in wt.\%): 41.6-47.4 Fe; 4.612.2 Ni; 0.1-0.9 Co; 0.1-3.7 Cu; 8.9-9.3 K; 32.9-34.7 $\mathrm{S}$; 1.3-1.5 Cl. Djerfisherite of melt pockets falls into field of one from groundmass of kimberlites of the Udachnaya-East pipe (Fig. 4). The individual grains of djerfisherite have lower $\mathrm{Ni}$ and $\mathrm{Co}$ and higher $\mathrm{Cu}$ and Fe then djerfisherite forming rims around early sulfides with high concentration of $\mathrm{Ni}$ and $\mathrm{Co}$ (Fig. 1 F). Probably djerfisherite rimming early sulfides has a reactionary nature.
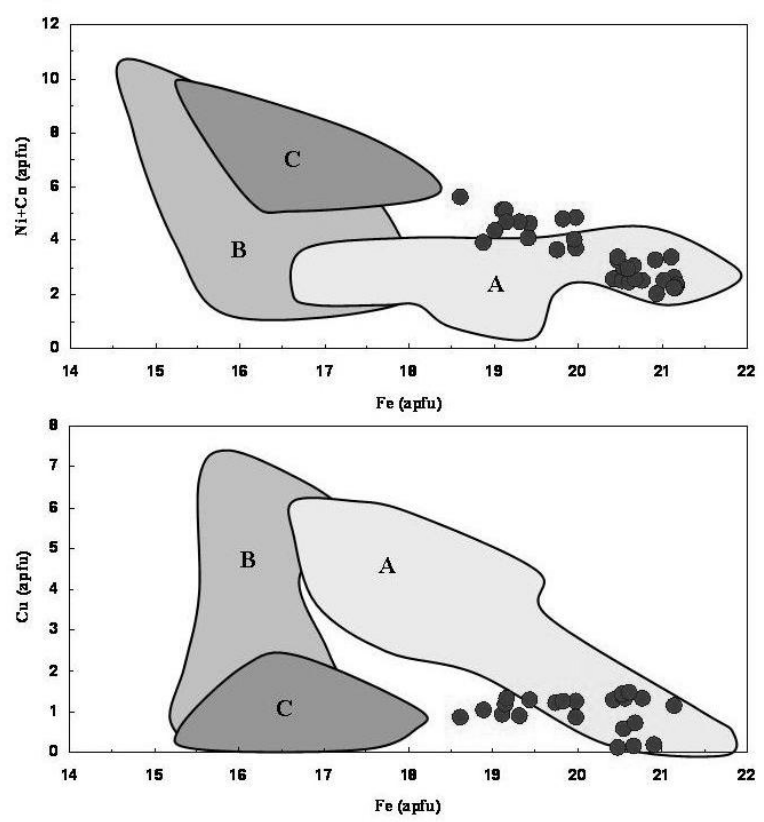

Fig. 4. Compositional variations (in apfu) of djerfisherite (solid circles) in the melt pockets in sheared lherzolite xenoliths. Compositional fields: A - from groundmass of kimberlites of the UdachnayaEast pipe (Sharygin et al., 2007); B - from melt inclusions in olivine from kimberlites of the Udachnaya-East pipe (Golovin et al., 2007; Sharygin et al., 2007); C - from sulfide inclusions in diamonds of Yakutia (Bulanova et al., 1990). 
Other sulfides. Monosulfide solid solution is characterized by wide compositional range (in wt.\%): 54.2-56.8 Fe; $5.1-9.9 \mathrm{Ni}$; $0.3-0.8 \mathrm{Co}$; up to $0.1 \mathrm{Cu}$; 34.7-36.2 S. Pentlandite shows the following compositional variations (in wt.\%): 39.6-44.1 Fe; 19.9$25.5 \mathrm{Ni} ; 1.0-2.5 \mathrm{Co}$; up to $0.1 \mathrm{Cu} ; 33.5-34.5 \mathrm{~S}$. The composition of pyrrhotite is (in wt.\%): 60.9-63.8 Fe; up to $0.4 \mathrm{Ni}$; up to $0.2 \mathrm{Co} ; 35.8-37.9 \mathrm{~S}$.

Perovskite is close to ideal $\mathrm{CaTiO}_{3}$ and contains (in wt.\%): 0.7-1.6 $\mathrm{Nb}_{2} \mathrm{O}_{5}$; 53.8-56.8 $\mathrm{TiO}_{2}$; 0.1-0.3 $\mathrm{ZrO}_{2}$; up to $0.6 \mathrm{ThO}_{2} ; 0.6-1.0 \mathrm{La}_{2} \mathrm{O}_{3} ; 1.0-2.6 \mathrm{Ce}_{2} \mathrm{O}_{3}$; up to 0.5 $\mathrm{Cr}_{2} \mathrm{O}_{3}$; up to $0.2 \mathrm{Al}_{2} \mathrm{O}_{3} ; 1.3-3.1 \mathrm{FeO}$; up to $0.3 \mathrm{MgO}$; 36.0-38.4 CaO; 0.2-1.2 SrO; 0.3-0.9 $\mathrm{Na}_{2} \mathrm{O}$.

Zoned spinel. The core is chromite $\left(\mathrm{Cr}_{2} \mathrm{O}_{3}\right.$ 47.9-56.4 wt.\%, $\mathrm{FeO} 23.0-27.2$ wt.\%, $\mathrm{MgO} 9.2-12.6$ wt.\%), the margin is magnetite $\left(\mathrm{Cr}_{2} \mathrm{O}_{3}\right.$ 0.3-5.1 wt.\%, FeO 68.084.2 wt.\%, $\mathrm{MgO}$ 3.5-14.6 wt.\%). The magnetite contains up to 9.4 wt. $\% \mathrm{TiO}_{2}$.

\section{Discussion}

Mineralogy of the melt pockets in studied xenoliths, excepting some minerals, resembles that of the kimberlites from the Udachnaya-East pipe. Zoned olivine, phlogopite, zoned spinel (chromite, Timagnetite, magnetite), perovskite, rutile, ilmenite, apatite, calcite, Na-K carbonates, halite, sylvite, pyrrhotite, djerfisherite and rasvumite were identified in groundmass of these kimberlites (Kamenetsky et al., 2004; Golovin et al., 2007; Sharygin et al., 2007a, $2007 \mathrm{~b}$ ). Moreover, compositions of most minerals from the melt pockets are similar to those of the kimberlite groundmass and some daughter phases of melt inclusions in olivine from kimberlites of the Udachnaya-East pipe (Kamenetsky et al., 2004; Golovin et al., 2007; Sharygin et al., 2007a). Olivine, chromite and pyrrhotite are the earliest minerals of melt pockets. The temperature of their crystallization estimated by the olivine-Cr-spinel pair (Fabries, 1979; Sack, Ghiorso, 1991) does not exceed $1050{ }^{\circ} \mathrm{C}$. The high concentration of $\mathrm{CaO}$ (up to $0.5 \mathrm{wt} . \%$ ) in olivine and the appearance of monticellite indicates low pressure of crystallization of the melt pockets, probably in shallow depth conditions. These facts suggest that origin of the melt pockets in sheared garnet lherzolites may be a result of infiltration of transporting kimberlitic melt or its derivates into xenoliths. Some interstitial sulfides may have primary mantle nature (Bulanova et al., 1990). Thus, the presence of melt pockets might have an essential influence on bulk major- and trace-elements composition of mantle xenoliths and should be considered when we are using these data for interpretation of evolution processes in mantle.

This work is supported by the Russian Foundation of Basic Research (grant No. 07-05-00072) and MK2138.2007.5.

References
Brey G.P., Köhler T., 1990. Geothermobarometry in four phase lherzolites II: new thermobarometers and practical assessment of using thermobarometers. Journal of Petrology, 31, 1353-1378.

Bulanova, G.P., Spetsius, Z.V., Leskova, N.V., 1990. Sulfides in diamonds and xenoliths from kimberlitic pipes of Yakutia. Publ. H. Nauka, Novosibirsk, 120 pp. (in Russian).

Fabries, J., 1979. Spinel-olivine geothermometry in peridotites from ultramafic complexes. Contributions to Mineralogy and Petrology, 69, 329-336.

Golovin, A.V., Sharygin, V.V., Pokhilenko, N.P., 2007. Melt inclusions in olivine phenocrysts in unaltered kimberlites from the Udachnaya-East pipe, Yakutia: some aspects of kimberlite magma evolution during late crystallization stages. Petrology, 15, 168-183.

Golovin, A.V., Sharygin, I.S., Korsakov, A.V., Kamenetsky, V.S., Pokhilenko, 2008. Alkali- and Cl-enriched carbonate-silicate melt inclusions in sheared lherzolite xenoliths from unaltered kimberlites of the Udachnaya-East pipe (Yakutia). 9IKC, Extended Abstract No. 9IKC-A-00061.

Harte, B., 1977. Rock nomenclature with particular relationship to deformation and recrystallization textures in olivine bearing xenoliths. Journal of Geology, 85, 279-288.

Ionov, D.A., Dupuy, C., O’Reilly, S., Kopylova, M.G., Genshaft, Y.S., 1993. Carbonated peridotite xenoliths from Spitsbergen: implications for trace element signature of mantle carbonate metasomatism. Earth and Planetary Science Letters, 119, 283-294.

Kamenetsky, M.B., Sobolev, A.V., Kamenetsky, V.S., Maas, R., Danyushevsky, L.V., Thomas, R., Sobolev, N.V., Pokhilenko, N.P., 2004. Kimberlite melts rich in alkali chlorides and carbonates: a potent metasomatic agent in the mantle. Geology, 32, 845848.

Misra C.K., Anand M., Taylor L.A., Sobolev N.V., 2004. Multi-stage metasomatism of diamondiferous eclogite xenoliths from the Udachnaya kimberlite pipe, Yakutia, Siberia. Contributions to Mineralogy and Petrology, 146, 696-714.

Sack R.O., Ghiorso M.S., 1991. Chromian spinels as petrogenetic indicators: thermodynamics and petrological application. American Mineralogist, 76, 827-847.

Spetsius Z.V., Taylor L.A., 2002. Partial melting in mantle eclogite xenoliths: connection with diamond paragenesis. International Geology Review, 44, 973987.

Sharygin, V.V., Golovin, A.V., Pokhilenko, N.P., Kamenetsky, V.S., 2007a. Djerfisherite in the Udachnaya-East pipe kimberlites (Sakha-Yakutia, Russia): paragenesis, composition and origin. European Journal of Mineralogy, 19, 51-63.

Sharygin, V.V. Kamenetsky, V.S., Kamenetsky, M.B., Seryotkin Y.V., Pokhilenko, N.P., 2007b. Rasvumite from the Udachnaya-East pipe: first finding in kimberlite. Doklady Earth Sciences, 415, 929-934.

Sobolev, N.V., Logvinova A.M., Zedgenizov D.A., Seryotkin Y.V., Yefimova E.S., Floss C., Taylor L.A., 2004. Mineral inclusions in microdiamonds and. macrodiamonds from kimberlites of Yakutia: a comparative study. Lithos, 44, 225-242.

Tracy, R.J., 1980. Petrology and genetic significance of an ultramafic xenoliths suite from Tahiti. Earth and Planetary Science Letters, 48, 80-96. 